\section{Islamic science}

Islamic Science: An Illustrated Study. By Seyyed Hossein Nasr. Pp. xiv +273. (World of Islam Festival: London, 1976.) $£ 12.50$.

A HANDSOME book, with 135 colour plates and 94 black-and-white pictures and diagrams, the photographs mostly by Roland Michaud. As for Seyyed Hossein Nasr's text, it may be recommended to those who already know enough about the subject to make allowances for the author's lack of objectivity and not to be led astray by his inaccuracies and his HumptyDumptyish way with words. Many of the author's convictions are shared by all reasonable people. But what the reader must bear in mind is that, although the implied contrast throughout is between the Islamic and nonIslamic worlds, what the author is really contrasting is the modern virtually world-wide technological civilisation on the one hand and an idealised Islamic Golden Age on the other. "In contrast to the modern situation, in traditional technology, of which many examples can still be seen in the Islamic world, the maximum possible recycling of all materials has always been the rule rather than the exception ... The use of every part of the sheep for purposes as far apart as feeding the family to providing fertiliser for the land to making strings for musical instruments is a case in point" (p234). A case in point indeed; it was no less true in eleventh-century Birmingham than in eleventh-century Baghdad.

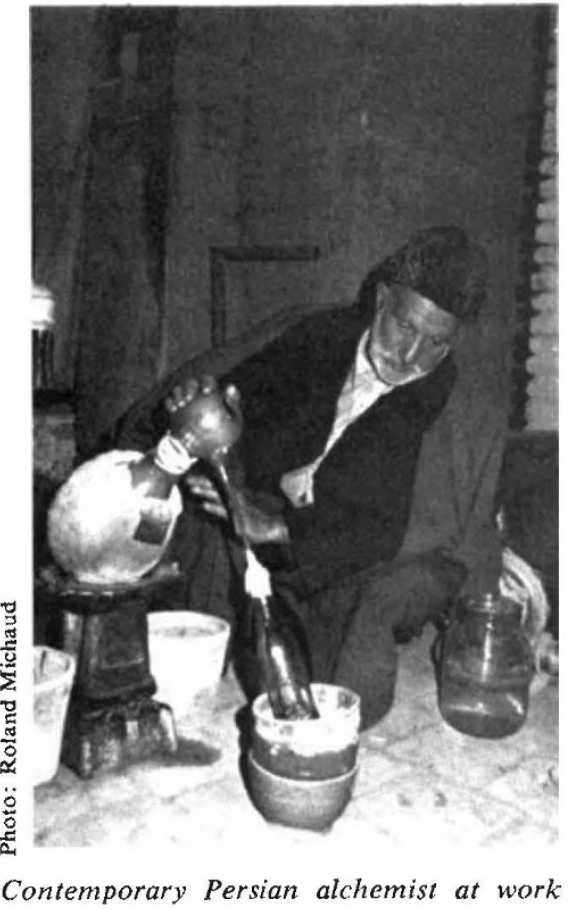

The central thesis of the book seems to be summed up on p150: "Islamic civilisation had the means to make complicated machines and apply them to the problems of the daily life of the Islamic community. But like the Chinese, who made gunpowder but never made guns, the Muslims never took that step which would mean the creation of a technology out of harmony with the natural environment." The comparison with China, by the way, would be more acceptable if the previous page were not devoted to illus- trations from Muslim works on the manufacture of cannon. Medieval Muslim men of science did not invent the steam-engine or the dynamo; nor did their Christian contemporaries, and no discredit to either party for that. But can one ascribe this failure to a conscious self-denying ordinance? It seems an affront to the genius of such men as al-Biruni and Ibn al-Haytham to suggest that they were less willing than any Western savant "To follow knowledge like a sinking star, Beyond the utmost bound of human thought." As for the other faults alluded to above, one example of each must suffice. "In Islam animals are never 'slaughtered'; they are only allowed to be killed ritually (dhibh)" (p244; for dhibh, incidentally, read dhabh). This will be about as meaningful to most readers as saying "In France people never 'drive' cars; they only conduisent them".

"In Islamic sources the one Hermes of Alexandrian sources became three, hence the term Hermes Trismegistos (from the Arabic al-muthallath bi'lhikmah) ..." (p198). As the term was in use in the early third century, $400 \mathrm{yr}$ before the coming of Islam, either Dr Nasr is wrong or someone in the Hellenistic world deserves credit for a remarkable piece of intelligent anticipation.

One feels a little mean at criticising so urbane a guide to Cloud-cuckooland; with caution on the part of the reader, this is a useful book. Even without, it is very beautiful.

G. L. Lewis

\section{Petroleum geology of North American continental shelves}

Canada's Continental Margins and Offshore Petroleum Exploration. (CSPG Memoir No. 4.) Edited by C. J. Yorath, E. R. Parker and D. J. Glass. Pp.898. (Canadian Society of Petroleum Geologists: Calgary, Alberta, 1975.) $\$ 19$.

THIS excellent book is unfortunately misnamed, and may be ignored by European geologists (and especially petroleum geologists), for whom it may be very useful. Essentially this volume describes the geology of the continental shelves of North America, from Vancouver on the west coast to Florida on the east coast, of the Arctic Shelves adjacent to Canada, Greenland, Svalbard and Russia, and of the Eastern Atlantic shelves from North Cape to Morocco. These areas are described on the basis of geophysical maps, seabed sampling, sparse well control and adjacent onshore geology. These data are interpreted in the light of plate tectonics theory, and most papers review the petroleum prospects in the areas concerned.

The volume contains 50 papers which were presented at two symposia: the Offshore Symposium held at St John's, Newfoundland in May 1974, and in Calgary, Alberta in September of the same year. The editors took the view that it was more important to publish the book in haste, with minimal editing, rather than to delay publication for careful editing and preparation. This was probably the correct decision. A page of errata is included; there seem to be few misprints. Because of this haste there are maps without scales (for example, p301, 302, 304, 309), metres and feet get used for vertical depths on facing pages in the same paper (p570, 571), some microphotographs have no scale (p626), some ornaments are not explained in keys (p651), and some gravity maps lack contour values (p304). Although the editors claim to have checked references for ease of retrieval, I defy anyone to track down those listed on $\mathrm{p} 852$.

Much of the material is new, at least to this reviewer. Some of the North American east coast data have been published previously in the bulletins of the American Association of Petroleum Geologists, and even of the Canadian Society of Petroleum Geologists itself. Similarly the material presented on the continental shelves of north-western, Europe will be familiar to those who have read Petroleum and the Continental Shelf of North-west Europe, edited by A. W. Woodland (for review, see Nature, 259, 607; 1976).

On balance, however, the editors are to be congratulated for having collated so much data on such a wide area from so many sources. This volume will provide a valuable source book for geologists, and especially petroleum geologists who are interested in the continental shelves of North America, the Arctic and Europe.

R. C. Selley 